\title{
INSTITUTIONAL CHANGES OF SOCIAL SECTOR: EXPERIENCE OF THE UNITED STATES AND JAPAN FOR THE DEVELOPMENT OF CHINA'S ELDERLY EDUCATION SYSTEM
}

\author{
Huo Zhiping, \\ Yin Haiyan, \\ Mykhailov Andrii, Dr. in Economics, Prof. \\ Sumy National Agrarian University, Sumy, Ukraine
}

As China enters the aging society, more and more attention has been paid to the education for the aged. The developed countries such as the United States, Japan that entered the aging society relatively early, in the elderly education have accumulated rich experience. By learning from their experience, we can better develop education for the aged and promote the development of human resources for the aged.

Key words: institutional changes in social sector, state social security reforms, state regulation of social protection system, aging population, elderly education, institutional diversification.

DOI: 10.21272/ 1817-9215.2019.1-13

\section{PROBLEM STATEMENT IN GENERAL}

China, as one of the fastest growing economies and population in the world, has made unprecedented growth during the past few decades. Nevertheless, with a rapidly aging population, continuous increase in cost of labor and exacerbating shortage of technical managerial talents especially top technical talents, China is facing serious new human resource challenges. Official figures from China's national bureau of statistics show in 2001 , the proportion of the elderly aged 65 and above was 7.1 percent, and the number of elderly people reached 90.62 million. According to the criteria set by the United Nations "Population Ageing and Its Socio-economic Consequences" in 1956, when the proportion of the elderly population aged 65 and over in a country or region exceeds $7 \%$ of the total population, it means that the country or region has entered the ageing stage. Therefore, China has entered an aging society since 2001 .

\section{ANALYSIS OF RECENT RESEARCH AND PUBLICATIONS}

At the end of 2018, the total population of the mainland China was 1,139.38 million, and the population over 60 was 249.49 million, accounting for $17.9 \%$ of the total population, of which the population aged 65 and above was 16,658, accounting for the total population $11.9 \%$ [1]. From the population data published in the statistical bulletin of national economic and social development of China national bureau of statistics from 2006 to 2018, we can also see that the elderly population in China presents a fast rising trend (see fig1). Since 2012, the working-age population has begun to decrease, and the demographic dividend has gradually disappeared, which means that the peak of China's population aging and the reduction of the labor force in the young and strong years (see fig2). In 2018, the number of elderly people aged 60-69 in China is 140 million, and in 2030, it will exceed 200 million[2].Based on the latest World Health organization (WHO) 2018 edition of World Health Statistics, the life expectancy of Chinese people is 76.4 years[3]. Moreover, when China started its reform and opening up in 1978, some old people who were in their youth easily accept new things and have strong learning ability. Through re-education, they could quickly acquire new knowledge and skills and engage in new jobs. Therefore, the 60-69year-old younger people are the main targets for the development of the elder human resources.

\section{FORMULATING THE GOALS OF THE ARTICLE}

The purpose of this study is to deepen the theoretical foundations for shaping the institutional changes of the social sector in the context of the implementation of the US and Japan experience for development of China's elderly education system. 


\section{OUTLINE OF THE MAIN RESEARCH MATERIAL}

The United States and Japan are two developed countries that entered into the aging society earlier. The education for the elderly develops earlier and at a higher level. They have accumulated many successful experiences which is of great reference significance for the development of China's elderly education in terms of theoretical guidance, policy formulation and mode selection [4].

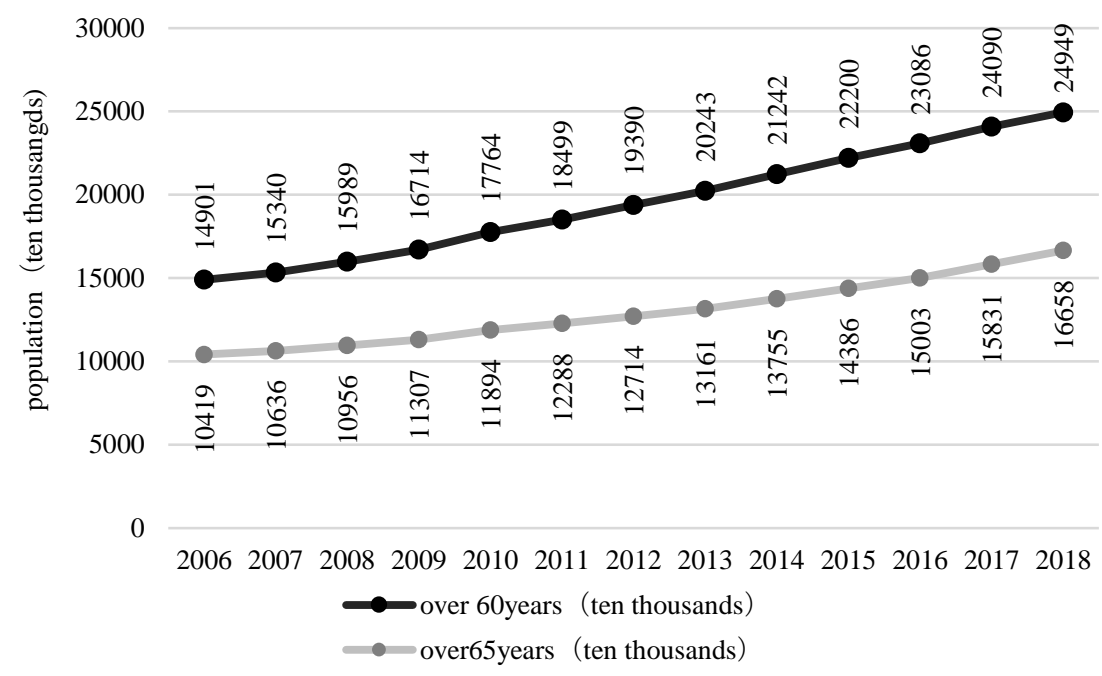

Figure 1 - Changes in China's population aged 60 and over 65 from 2006 to 2018 (Source; Statistical bulletin of the People's Republic of China on national economic and social development 2006-2018)

The main experience of the elderly education in the United States. First, US established a complete legal system for the elderly education and numerous management institutions and organizations for the elderly education. Successive US governments advocated the establishment of a lifelong education system and successively promulgated the lifelong education act, the American law on the elderly and the no discrimination against the elderly act, providing legal basis and financial support for the elderly education in the United States.

In organizing and managing education for the aged, the US government encourages and guides various non-governmental educational organizations to participate in education for the aged in addition to setting up special administrative agencies. Varieties of nongovernmental for-profit or non-profit elderly education organizations are more numerous. They carry out various forms of elderly education activities according to the learning needs of the elderly, making outstanding contributions to the enrichment and development of elderly education in the United States.

Second, the form of organization relies on community to carry out diversified education for the aged. The main mode of elderly education in the United States is to implement various forms of elderly education relying on community resources. In the United States, in addition to universities for the elderly, there are centers for the elderly, study Tours for the elderly, etc., which provide free or paid education for the elderly, as well as self-education, distance education and so on. In the United States, there is a boarding school for the aged over 60 near the university, which is convenient for the aged to live and study nearby.

Third, the emphasis is on the theoretical research of geriatric education and the development of geriatric human resources. The achievement of American geriatric education is closely related to the American theoretical research on geriatric education. The deepening of the theory of geriatric education also deepens the understanding of the value of geriatric human resources, and geriatric education has become one of the main means of the development of geriatric human resources. 


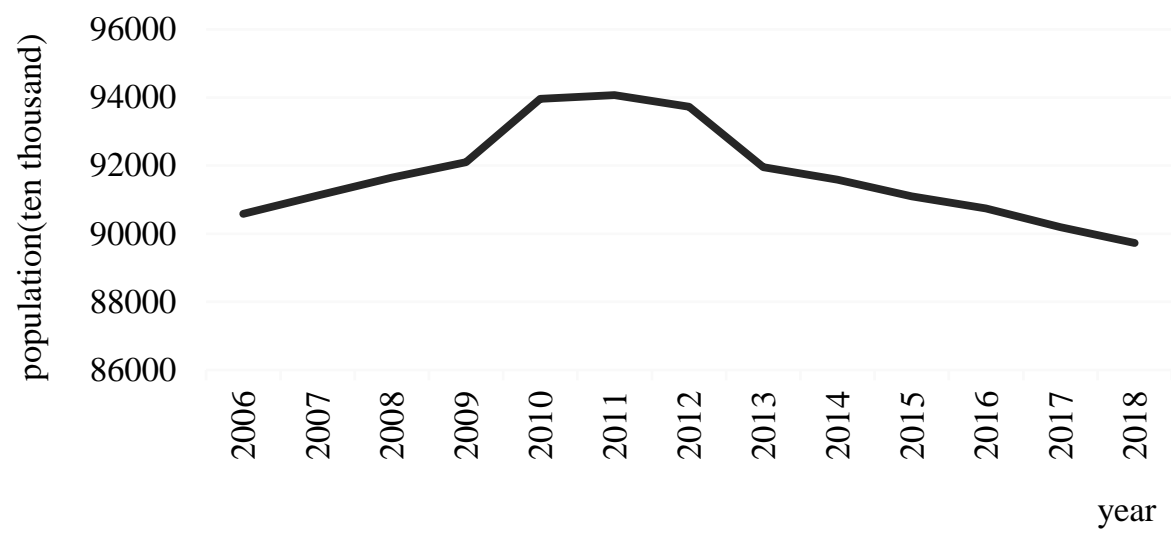

Figure 2 - Changes in China's working-age population from 2006 to 2018

(Source: Statistical bulletin of the People's Republic of China on national economic and social development 2006-2018)

The main experience of the elderly education in Japan. First, the subject of the elderly education is diversified. In the 1970s, under the guidance of the concept of "lifelong education", the Japanese government began to intervene and lead the education for the aged, and the subjects of its implementation were diversified. Administrative education departments, government welfare departments, institutions of higher education and various non-governmental organizations all take part in elderly education through various forms to provide multi-level and diversified learning needs for the elderly [5].

Second, the elderly education curriculum system is rich, the curriculum content is rich, and the teaching method is diverse. Japanese elderly education curriculum is very rich, according to the needs of the overall development of the elderly, the design of different levels and content of the curriculum. In terms of teaching methods, it pays attention to the participation and subjectivity of the teaching objects and arouses students' enthusiasm and interactive ability in the teaching process.

Third, they pay attention to integrating old-age welfare programs with education for the elderly. In Japan, the welfare administrative departments of different levels of government will hold universities for the aged in different forms. Welfare and health care account for a large proportion in educational activities, and the ultimate goal is to promote the physical and mental health development of the elderly.

Conclusion. China's real development of elderly education and research time is after the reform and opening up compared with the United States and Japan, on the elderly education development theory understanding is insufficient, laws and regulations are not perfect, urban and rural elderly education development is not balanced, the elderly education training content is lack of problems.

Therefore, firstly, our country must change the understanding from the government to the society, and strengthen the theoretical research on the elderly education. In recent years, China has gradually attached great importance to the education for the aged, especially in large and medium-sized cities. The education for the aged has been put into a certain position. All kinds of universities for the aged have also made great progress, and their number and scale have been greatly improved. In the 13th Five-Year Plan (2016-2020), the Chinese government mentioned the promotion of the development of old-age learning. According to data released by the China Association of Senior Citizens, there are more than 70,000 educational institutions for the elderly, including universities [6]Practice has proved that the active development of education for the elderly is not only a positive measure to cope with the challenges of aging, but also an important way to implement the concept of "lifelong education". 
Secondly, we should speed up the construction and improvement of the legal system for education for the elderly, which will provide fundamental guarantee for the development of education for the elderly. One of the main reasons why education for the elderly is guaranteed in the United States and Japan is that there are relatively good legal provisions. In recent years, China has gradually attached great importance to the legal construction of lifelong education for the elderly. It is mentioned in relevant laws and regulations that we should attach importance to the education for the elderly, but there is no special education law for the elderly in China. In order to promote the development of education for the aged, the government must make special laws and regulations.

Thirdly, we should attach importance to the development and utilization of elderly human resources. At present, there are some misunderstandings about the aged human resources in China, and the value of the aged human resources is not fully realized. Some retired old people, especially young healthy professionals, have great potential for development and can contribute to new positions through training and learning.

Fourth, the government should encourage ordinary institutions of higher education and other educational institutions to participate in the education of the elderly. As of May 31, 2017, there are 2,914 institutions of higher learning nationwide, including 2,631 ordinary institutions of higher learning (including 265 independent colleges) and 283 adult institutions of higher learning [7].However, most colleges and universities do not have a high degree of participation in education for the aged and lack of theoretical research on education for the aged. China should learn from the practice of the United States and Japan, where the potential of the general institutions of higher education should be open to the region's elderly, open a variety of courses, to provide education services for the elderly. The university that the condition allows also can develop old age education through the means of long-range education.

At present, under the call of the government, senior management departments in various parts of China take the initiative to connect with schools of various levels and types, promote the opening of venues, libraries and other resources to the elderly in the region, and provide curriculum resources for the elderly in ordinary universities and vocational colleges. Take the initiative to contact departments, industrial enterprises, universities and other institutions for the elderly from the service of the unit, the system retired workers to the service of the elderly. We will actively promote the diversification of organizers and financing channels, support and encourage all kinds of social forces to organize or participate in elderly education through sole proprietorship, joint venture and cooperation through government purchase of services and project cooperation. On May 29 2019, Premier Li Keqiang of the State Council presided over the executive meeting of the State Council, and put forward the preferential policy for the establishment of universities for the aged by social forces. In this way, government departments will give certain support to universities founded by social forces in terms of funds and policies, which will be conducive to the sustainable development of the whole education industry for the aged.

Only by accelerating the development of education for the elderly, can we promote the development of human resources for the elderly, provide high-quality labor force for China's economic development, and alleviate the labor shortage caused by the aging population.

\section{REFERENCES}

1. Statistical communique on China's national economic and social development in 2018. National bureau of statistics [Online]. Available at:http://www.stats.gov.cn/tjsj/zxfb/201902/t20190228 1651265.html

2. Population aging national education lecture hall report. [Online]. Available at: http://www.cncaprc.gov.cn/channels/868.html

3. Population Division of United Nations World Health Statistics of WHO 2018. WHO

4. Han Shujie. (2006). Successful experience and enlightenment of American education for the aged. Journal of college of adult education, hubei university, 24(1), 52-55.

5. Han Shujie. (2006). Implementation methods and implications of elderly education in Japan. Journal of Inner Mongolia normal university: educational science edition (7), 43-45.

6. Chinese association of universities for the aged [Online]. Available at: http://www.caua1988.com/index.asp

7. Ministry of education of the People's Republic of China [Online]. Available at:http://www.moe.gov.cn/srcsite/A03/moe_634/201706/t20170614_306900.html 